\title{
カリフォルニア州ヴェンチュラ海岸の海岸侵食 とダム堆砂の除去に関する一考察
}

A NOTE ON BEACH EROSION OF VENTURA COAST IN CALIFORNIA AND PLANNING OF REMOVAL OF DEPOSITED SEDIMENT IN UPSTREAM REGION OF A DAM

\author{
宇多。高明
}

Takaaki UDA

\author{
正会員 工博 建設省土木研究所 河川部長（テ305-0804 茨城県つくば市旭1）
}

\begin{abstract}
Beach erosion of the Ventura coast in California was investigated by field observation. On this beach, located on the downcoast of the Ventura River mouth, where eastward longshore sand transport dominates, beach erosion was triggered by the obstruction of continuous sediment supply from the Ventura River by the construction of Matilija Dam. Removal methods of deposited sediment in upstream region of this dam, and their effects and influences to the riverbed and the coastline were discussed in Sand Right '99 symposium held in Ventura. This study summarizes the results of this symposium as well as the results of field observation, and future measures in Japan are discussed through the comparison.
\end{abstract}

Key Words : Beach erosion, Sand Right '99, Ventura River, sediment supply, field observation

\section{1.まえがき}

わが国では,山地から海に至る水系の管理がいく つもの機関によって行われてきた.この結果,局所的 に最適化された計画も,水系全体で見ると自然の系 から大きくかけ離れてしまい,様々な弊害が目につ くようになってきた.水によって運ばれる土砂の系 (流砂の系)についても同様な状況にあり,ダムなど では過剩な堆砂に悩まされる一方,河川では河床低 下が問題となり,あるいは海岸の侵食が激化するな どの現象が生じている.こうした問題を解決するた めには,まず問題の所在を正確に把握し,それに基づ いて各種対策を検討しなければならない。建設省で も,河川審議会の答申に基づいて, 現在,水系一貫の 土砂管理に関する各種検討を進めている．ところで， このような問題はわが国でとくに目立ってはいるが, 同様な問題が生じている国々も多い.そのような事 例を検討することは,わが国での対策立案にも有効 であろう。米国カリフォルニア州のヴェンチュラ郡 に流域を持つヴェンチュラ川の上流にある,マティ リハダムでは堆砂がひどいために,ダムの一部また は全体の撤去計画がある.そして,そのままダムを撤 去した場合の土砂移動,ダンプトラックによって海 岸まで土砂を輸送して養浜した場合の海岸線の変化 などが数值シミュレーションによって検討されてい る.1999年9月末,海岸侵食やダム堆砂など,土砂に係 わる問題についての議論を目的としたシンボジウム (Sand Right '99 : 「砂の権利'99」)がヴェンチュ ラで開催された。筆者はこのシンポジウムに出席し て議論に加わるともに，現地調査を行った。ここでは

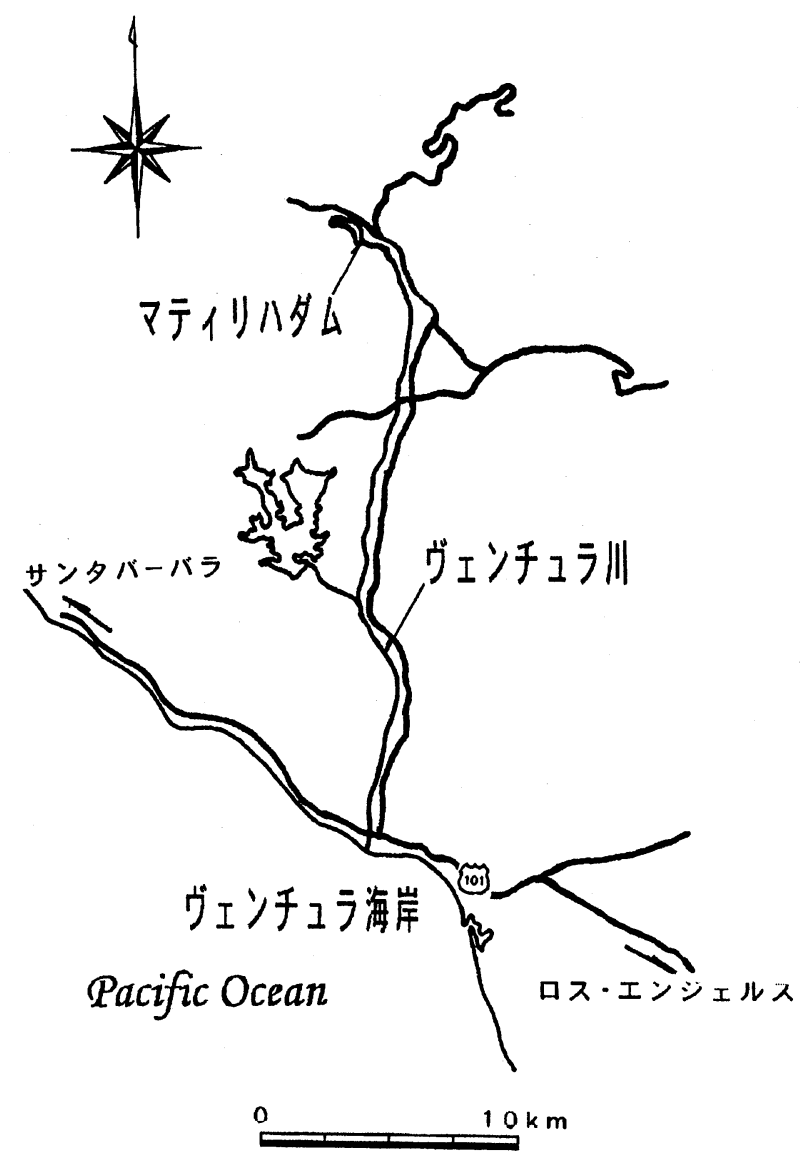

図-1 マティリハダム平面位置図 
これらの調查の結果について報告し,それをもとに 考察を加える。

\section{2. ヴェンチュラ川とマティリハ( Matilija ) ダムの概要1)}

図-1には調查区域のヴェンチュラ郡とその周辺の 海岸の位置図を示す.ヴェンチュラ郡はロス・エン ジェルス (Los Angels) の北西約 $110 \mathrm{~km}$, サンタバー バラ(Santa Barbara)の東約 $45 \mathrm{~km} に$ 位置し, 沖合の チャネルアイランド(Channel Islands)に囲まれた 海域に面している.沖合にチャネルアイランドが あって南側からの波が遮蔽されているために, 主な 波浪は西側から侵入する.このため,ヴェンチュラ郡 の海岸では全体として東向きの沿岸漂砂が卓越して いる。

マティリハダムはヴェンチュラ川の主な支川のマ ティリハ・クリークにあるアーチダムである.この ダムは,ヴェンチュラ郡の洪水対策事務所によって 利水および洪水制御を目的として1948年に建設され た.建設当初のダムの高さは約 $57 \mathrm{~m}$, ダム頂部の幅は

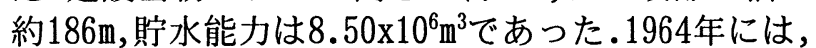
アルカリ骨材反応によってダム頂部にクラックが発 見されたため,ダム頂部が約 $9 \mathrm{~m}$ 撤去された.ダムの建 設後, 洪水により土砂が堆積し, 現在の貯水能力は $1.09 \times 10^{6} \mathrm{~m}^{3}$ （当初貯水容量の約 $13 \%$ ）にまで減少し, 洪水調節効果および水資源確保上の効果もほとんど なくなっている.マティリハ・クリークのダム上流

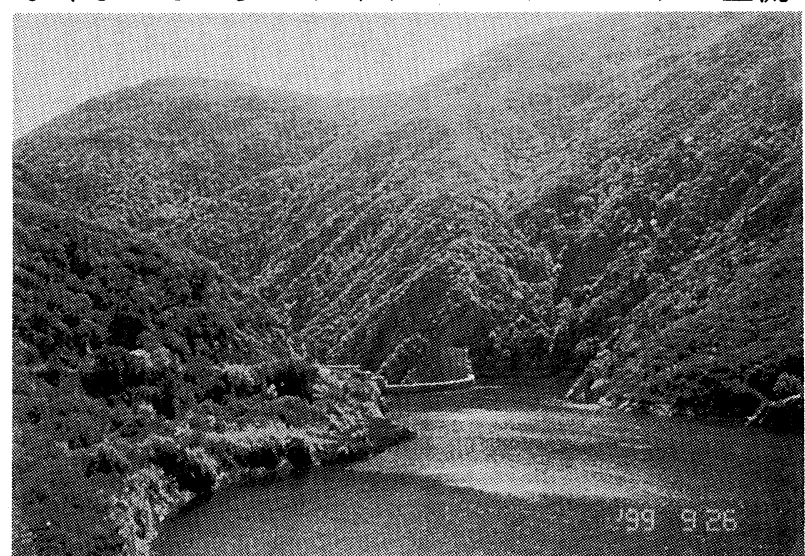

写真-1 マティリハダムとその上流の湛水域

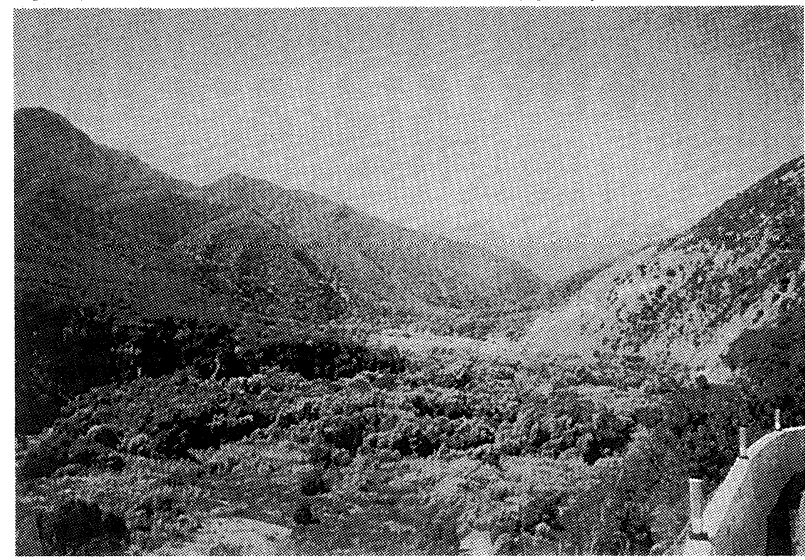

写真-2 マティリハダム上流の流域
部には,絶滅危惧種のマスの生息地があったが,ダム 建設によってその生息地が失われた.現在,ダム自体 の撤去が計画されており,それが実現すればマスの 生息地の増大に寄与すると考えられている。

ダム上流に堆積した土砂は,海岸での養浜材とし て有効利用が可能である.そのためヴェンチュラ郡 および開拓局ではダムの撤去あるいはその高さを下 げることについての可能性検討を進めるとともに， 堆積土砂を利用した海岸における養浜についての検 討が行われている.ダム本体の撤去は従来工法で可 能であるが, 問題はダムにたまった $3.8 〜 4.6 \times 10^{6} \mathrm{~m}^{3}$ の 土砂の除去にある.ダム下流に直接排出すれば,洪水 の原因となる.また水生生物に大きなマイナス効果 を及ぼすとともに,各種取水施設にも影響するであ ろう.このような状況下で, 各種の案が検討されてい る.第1案は,ダムを切り下げた後, 河川流によって海 まで運ばれるのを待つ方法, 第2案は浚渫したスラ リーをパイプによって海岸まで輸送する方法,第3案 は乾燥させた土砂をトラック輸送する方法である。 これらの相互比較が行われている11.

\section{3. 現地調査}

ヴェンチュラ川と,その支川のマティリハ・ク リークに建設されたマティリハダム, およびヴェン チュラ海岸の現地調査は1999年9月25,26日に行った。 以下では写真をもとに現地状況を明らかにする。

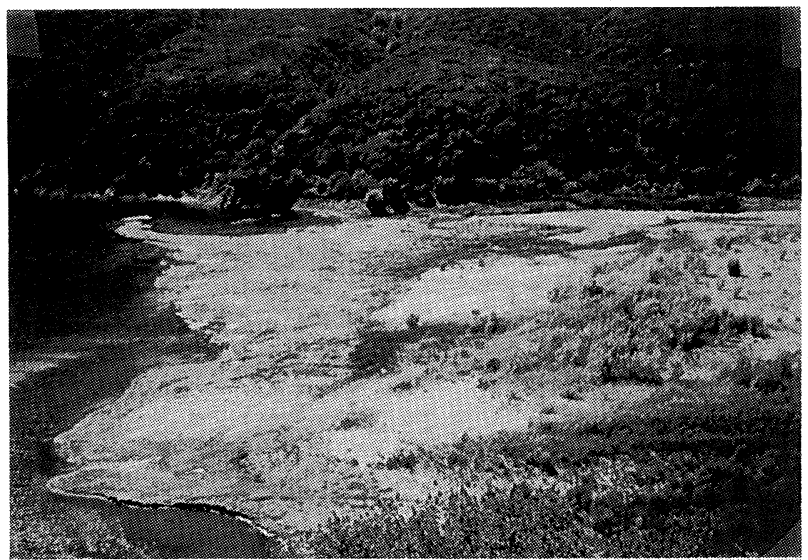

写真-3 ダム湖上流端における土砂の堆積状況

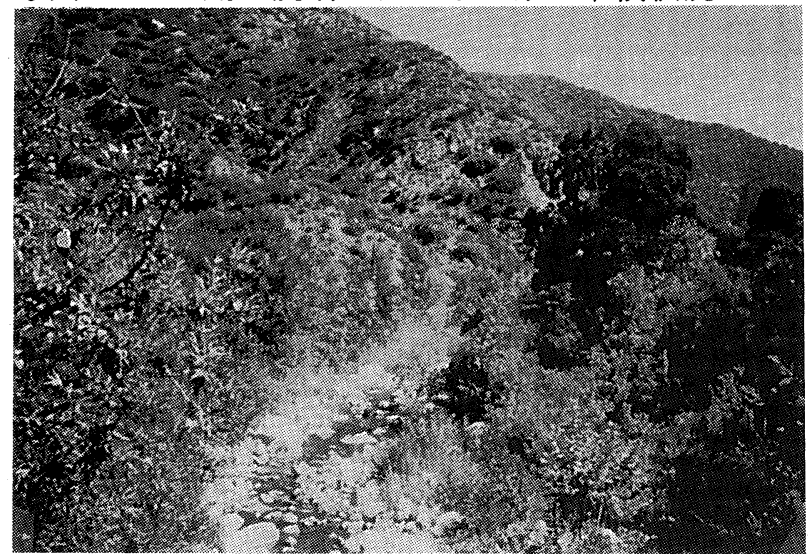

写真-4 マティリハ・クリークのダム直下の河床状況 


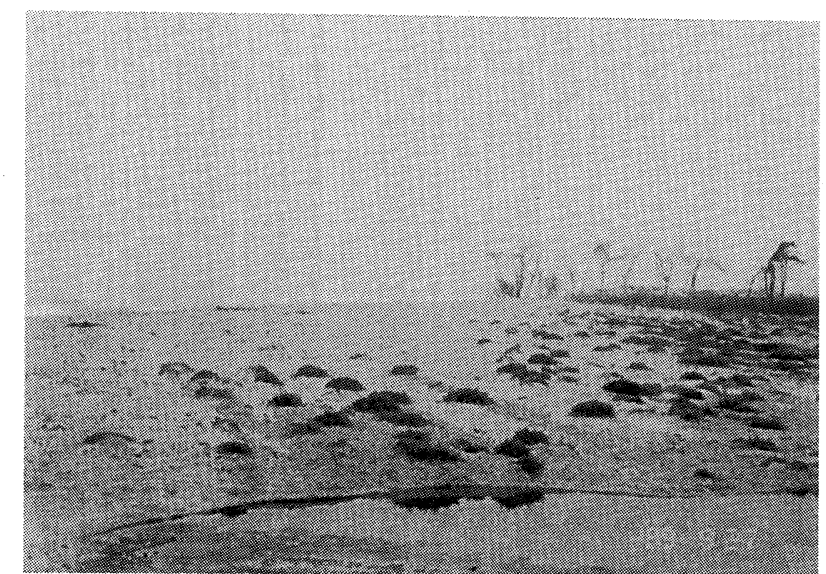

写真-5 ヴェンチュラ川河口の右岸砂州

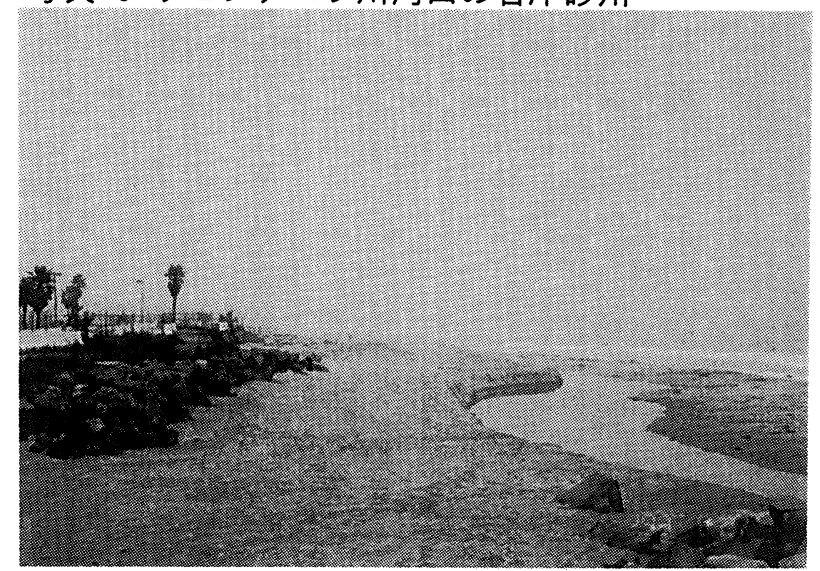

写真-6 大きく東向きに蛇行して流れるヴェンチュ ラ川の河口部流路

（1）ヴェンチュラ川およびマティリハダムの状況

写真-1はマティリハダムとその上流の貯水地の状 況である.アーチダムの両そで部が切り下げられて いるが,この理由は上述した通りであり,切り下げ部 の高さは約 $9 m$ である.このダムがある付近は,海岸か ら約 $25 \mathrm{~km}$ 内陸に入った場所で砂漠地带に属する.写 真-1に示したダム上流の流域を撮影したのが写真-2 である.流域は乾燥地帯にあるために, 背丈の低い灌 木が地表面を覆っている.写真-2より下流側の貯水 池の上流端を撮影したのが写真-3である.洪水によ り運ばれた土砂が貯水池を埋め,そこにできた土袞 の上に植物が繁茂している.写真に示すように,洪水 のたびに上流側から土砂が堆積し,貯水池面積が狭 まっている.写真-4は,ダム直下のマティリハ・ク リークの河道状況である.写真に示すように, 河床は 巨鿬で覆われておりその周辺に植生が繁茂している。 巨碟で覆われた河道状況から判断して,この付近の 河道の河床勾配は数十分の一程度の急勾配であるこ とが推定される。この川を経由して海岸へと土砂が 運ばれ,それが海浜の形成に役立ってきたが,ダム堆 砂とともに海岸へ供給される土砂量が減少している.

\section{(2) ヴェンチュラ海岸}

1999年9月25日,ヴェンチュラ海岸の現地調査を 行った.調查は,ヴェンチュラ川河口から東向きに徒 歩で行った.写真-5はヴェンチュラ川河口に形成さ
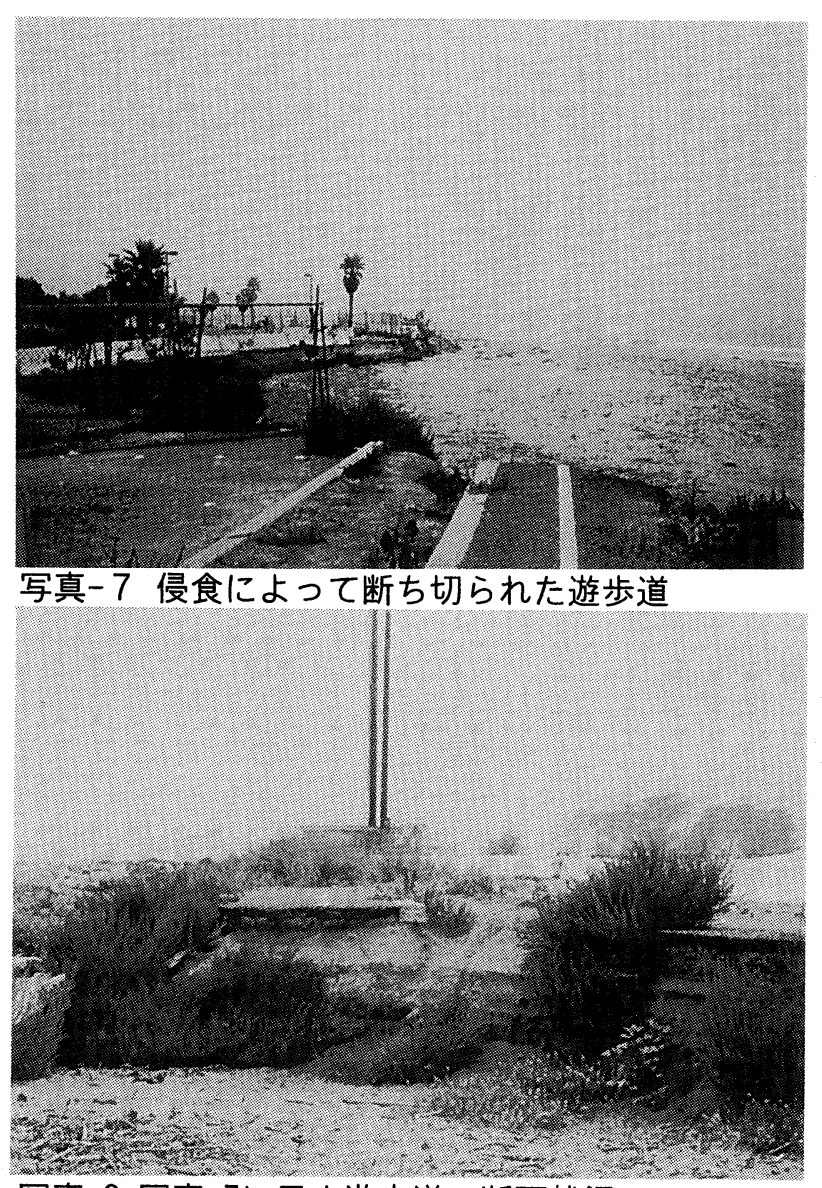

写真-8 写真-7に示す遊歩道の断面状況

れた砂州である.この河口砂州は西側ほど広く,細砂 で構成されている.写真手前側には狭い水域が見え るが,これはヴェンチュラ川河口の水路の一部であ る.この砂州を構成する砂の大部分は, 河口より西側 に位置し,サンタバーバラまで続く海岸線に発達し た海食崖からの供給土砂である.東向きの沿岸漂砂 によって運ばれた土砂が河口を西側から塞ぐために， 河口は束侧以と大きくずれている.また写真に見え るように,河口砂州上に繁茂した小さな植生の手前 側と前方で砂面の色が異なり,植生の前方には乾い た白っぽい砂があるのに対して, 植生の手前側には 湿気を含んだ砂があるのは,この河口では前方の汀 線から飛砂によって河口内へと土砂が運ばれている ためである。

写真-6は,写真-5で下部に見える細長い流路を,流 下方向に撮影したものである.写真撮影時, 流量が非 常に小さかったために, 河川流は沿岸漂砂の下手方 向に大きく蛇行して流れ,その後海へ流入している. このように流路が東側に大きくずれた河口状況自体， ヴェンチュラ川河口部での東向きの沿岸漂砂の卓越 を明瞭に示している。

ヴェンチュラ川は東向きの沿岸漂砂の卓越する海 岸に流入している.このため河口部から土砂を運び 去る効果をもたらす沿岸漂砂量と比較して, 河川か らの土砂供給量が十分大きければ河口デルタが形成 されて海岸線は突出する.逆に流出土砂量が小さく なれば河口部海岸線は後退する。ヴェンチュラ川河 


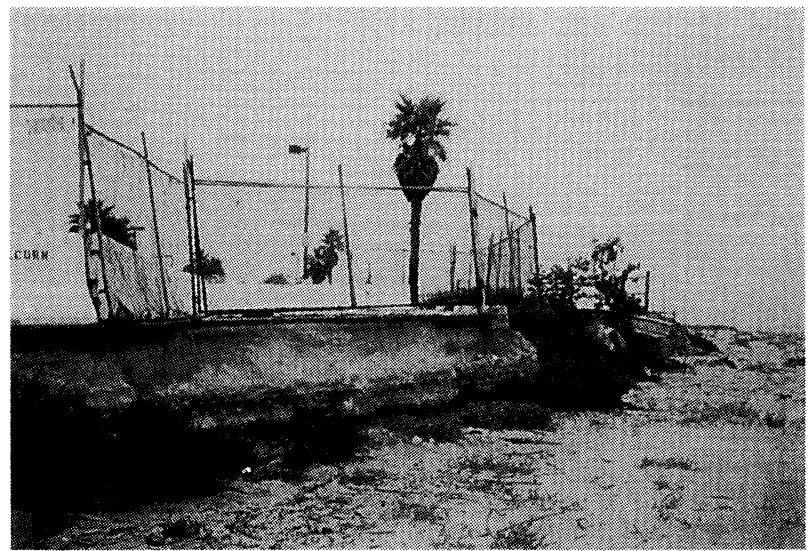

写真-9 侵食されて流出した遊歩道の基礎

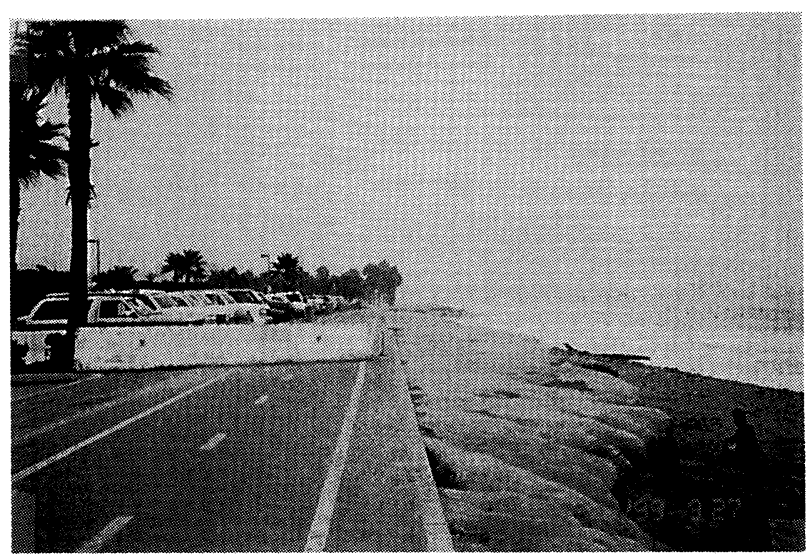

写真-10 閉鎖された遊歩道とその海側の半固結状態 の土層

ロでは過去に流出土砂量が大きかったために河口部 の海岸線は大きく突出している.このような条件下 で河川からの供給上砂量が減少すると, 斜め入射波 の条件下で突出した河口デルタの左岸側で海岸侵食 が著しくなる。

写真-7は,写真-6の左端付近の海岸状況である.海 岸線に沿って造られていた遊歩道が突然切れており, 遊歩道は閉鎖されている.写真-7の位置を逆方向か ら望んだのが写真-8である.高さ約1mほどの崖が形 成されて遊歩道が削り取られている.遊歩道の基礎 は,乾燥した半固結の土層である.侵食された後には 海浜砂が堆積している.また土層には層状構造が見 えることから,この付近は天然の土層が侵食された ことがわかる.写真-8の左端に一部見えるように,河 口左岸は捨石護岸によって守られているために侵食 されなかったが,河口すぐ左岸側の海岸が波の作用 で侵食され,遊歩道が削り取られたのである。写真-9 は遊歩道があった場所を東向きに撮影したものであ り,ここでも同じように浜崖が形成されている。

写真-9に示した付近より東側の, 河口からの距離 が大きい場所でも海岸侵食は進んでいるものの, 遊 歩道が壊れるまでには至っていない.写真-10は海岸 線に沿った遊歩道と,その海側の自然海岸の侵食状 況である.遊歩道の海側には半固結の土層が露出し ており,この土層の前面にはほぼ垂直な面が形成さ れている.写真-11は礫浜上から崖を撮影したもので

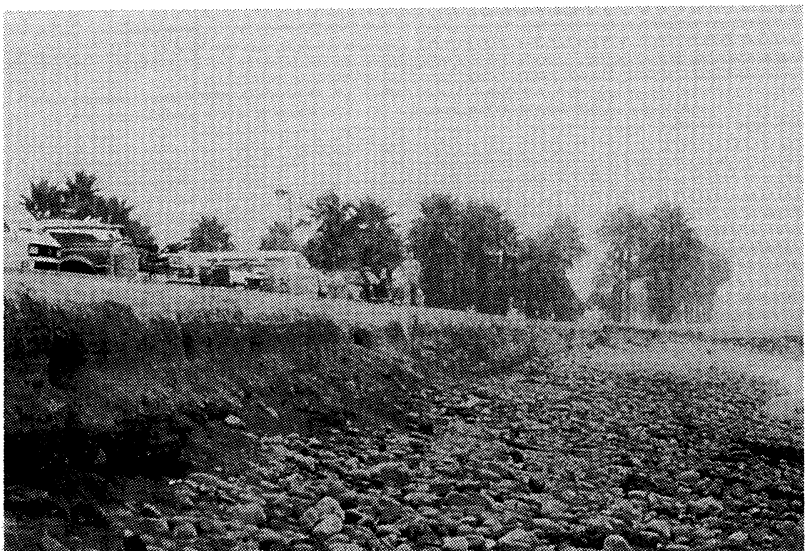

写真-11 半固結状態の土層の側面と下部の碟層およ び碟浜

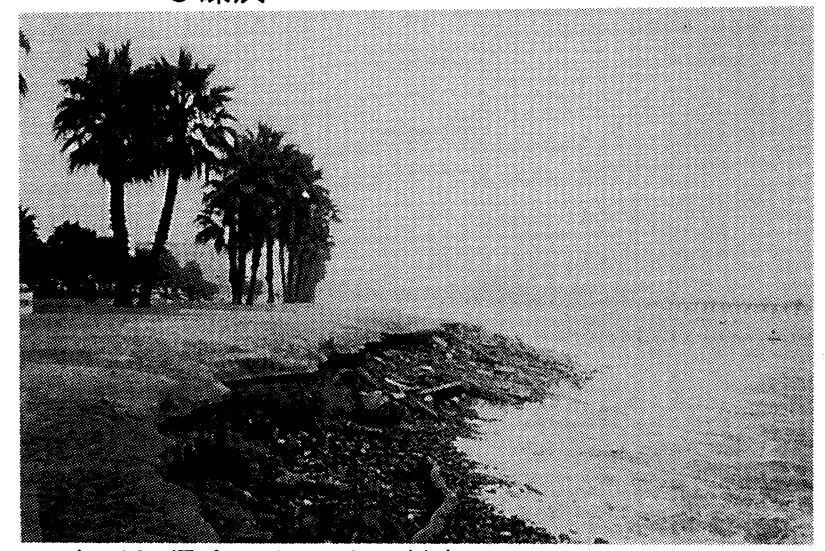

写真-12 侵食された人工地盤

あるが,土層の下部には礫層が見える.沿岸漂砂の上 手側に位置するヴェンチュラ川の河口付近では海浜 は細砂で構成されており,砅は見られなかったこと を考慮すると,この付近で見られる前浜上の硌は崖 の後退とともに前浜上に出現した可能性が大きいと 考えられる.また,半固結の土層の海側を覆う砂が， 波の作用によって小規模な崖面の下部に衝突すれば, 崖の侵食が助長されると考えられる。

写真-11では前方に多数のヤシ木が見える.ここで は汀線が沖向きに突出している.その原因は後述す るようにコンクリート製の排水樋管が突堤と同様な 働きをして漂砂移動を阻止しているためである.写 真-12は海岸線の突出部の全景である.写真を詳細に 観察すると,汀線付近には砂だけではなく,多くのコ ンクリート片も散乱している.崖面には砂層が見ら れず,コンクリート片などが多く含まれている.これ より,この付近はもともと人工的に造られた地盤で あり,それが侵食されて建設時の地盤材料が露出し たと推定される.写真-13は会議の行われたホテルの 屋上より,南西方向を向いて撮影したものである.海 岸線が最も突出した部分には写真-14に示すような 排水樋管があり,それが東向きの沿岸漂砂を阻止し ている.その手前側で, 写真では直線状に見える海岸 線は砂で覆われている.この付近はヴェンチュラ川 の河ロデルタとして岬状に突出している.沖合の等 深線が半円形状に突出しているため,そこは良好な サーフスポットになっている. 写真に示すように斜 


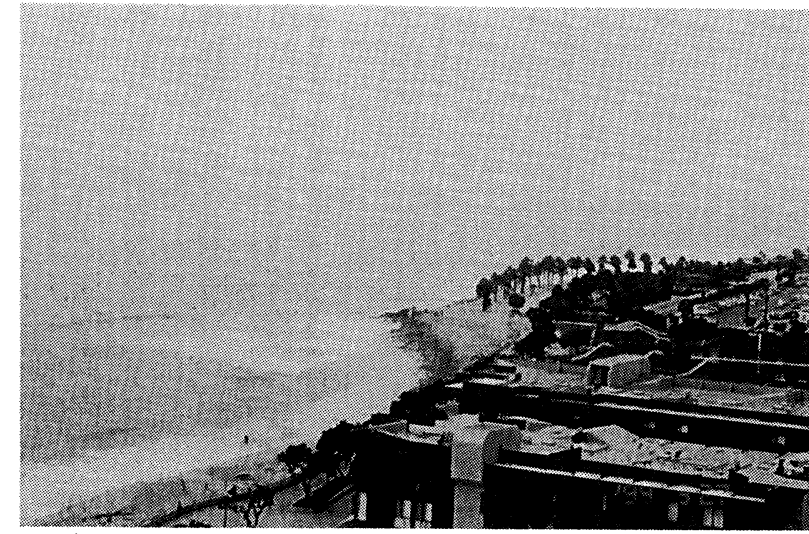

写真-13 会議場のホテルの最上階から見たヴェン チュラ海岸のサーフスポット

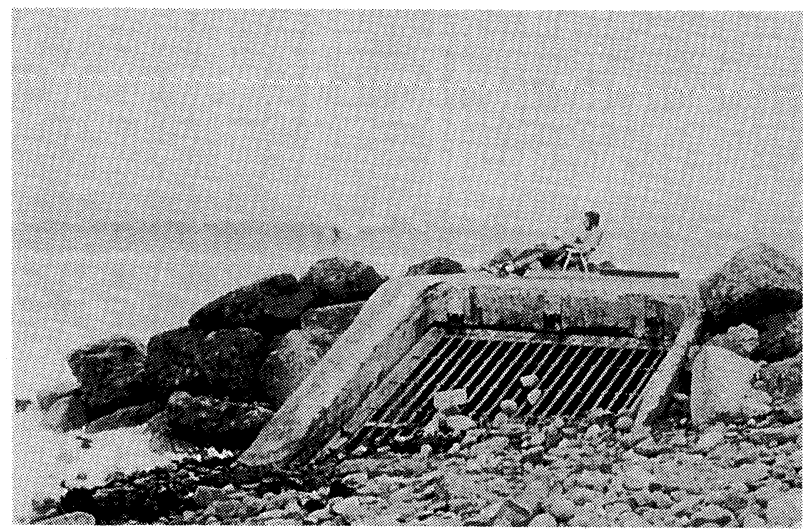

写真-14 海岸線に設置され,突堤効果を発揮してい る排水樋管

め入射波が屈折しながら徐々に砕波することがサー フィンに良好な波浪条件を与えている。

写真-15は, 写真-13,14に示した排水樋管の東側の 海岸状況を示したものである.海岸線に沿って建設 された遊歩道に所々展望台が設置されているが,そ の前面にはごく狭い磁浜が広がっているのみである。 またこの付近で海岸線の方向が大きく変わり,写真 前方に見えるホテル（シンポジウムの会場）の手前 側からは砂浜が広がり,砂浜幅は次第に増す。写真16は,ホテルの部屋から砂浜を見下ろしたものであ る.ヴェンチュラ栈橋より南側, ヴェンチュラ港との 間には突堤群が配置されている.写真-17は捨石製の 突堤と,その両側の海浜状況を撮影したものである. 突堤の北西側の汀線は南東側の汀線より突出してい ることが明らかであり,このことからここでは南東 方向の沿岸漂砂が卓越していることがわかる.

ヴェンチュラ海岸では写真-16に示す区域は細砂 で覆われているのに対し,写真-13に示したように ヴェンチュラ川河ロデルタの東側隣接区域の, 海岸 線が沖向きに突出した部分の海岸線は碟で構成され ている.これはヴェンチュラ川河ロデルタの左岸側 は海岸線が突出しているため波浪の作用を強く受け, 沿岸漂砂量が大きいことが原因である.現況で海岸 線は礫で覆われているが, 細砂は急速に東向きに流 され,写真-16に示した下手側の海浜に運ばれ堆積す ると言える。

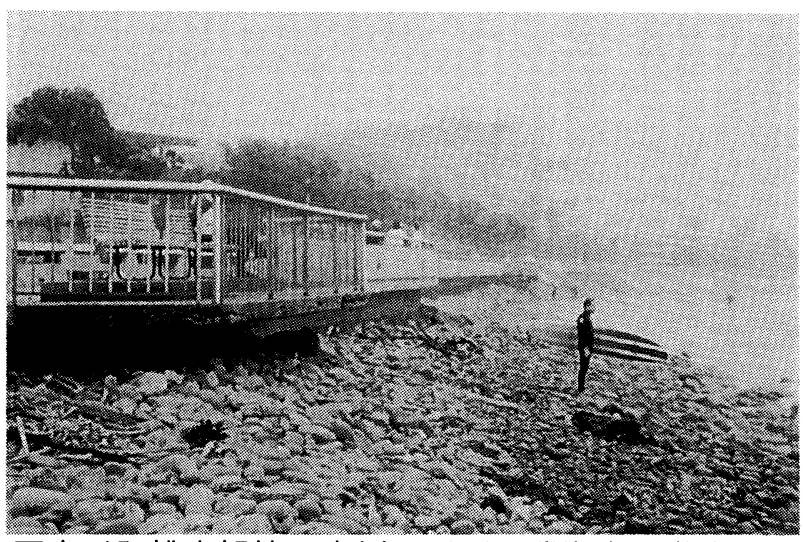

写真-15 排水樋管の東側に延びた砂海岸と遊歩道

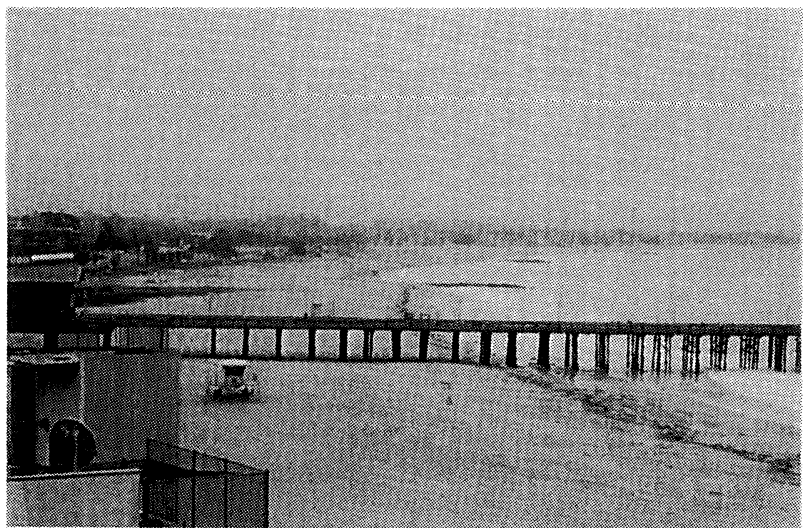

写真-16 ヴェンチュラ栈橋とその南にある突堤

\section{4. 考察}

前節で明らかにしたように,ヴェンチュラ海岸で は海岸侵食が進んできている.海岸侵食は,地形的に 見て河口デルタが海側に大きく突出していることか ら,河口東側の海岸線で顕著であり, しかも河口に近 接するほど状況が悪くなっている.このような侵食 はヴェンチュラ川から土砂が大量に供給されておれ ば起こらない現象である.その意味ではダム堆砂を 養浜材として利用する可能性について検討すること は有意義である.ただし,ヴェンチュラ川河口より西 側の海岸でも侵食が進みつつあるが,このことは全 体的に海岸線への供給土砂量が減少したこと,そし て土砂供給が減少したのはヴェンチュラ川のみでは ないことを意味する.ヴェンチュラの西約 $45 \mathrm{~km}$ に位 置するサンタバーバラでは1927-28年にサンタバー バラ港が建設され，この防波堤によって東向きの沿 岸漂砂が阻止された.この結果,そこより東側に位置 する海岸への供給土砂量が減少している22.これもま た海岸侵食の大きな要因となっている.

ヴェンチュラ川とヴェンチュラ海岸は,わが国の 中部山岳地帯を流れ下る河川と,その河口から広が る海岸の侵食問題と非常に類似している。例えば,駿 河湾西岸に流入する大井川と駿河海岸, 安倍川と静 岡・清水海岸の事例が類似事例である.この意味よ り,ヴェンチュラ川水系で行われている数々の試み は参考になると思われる。 


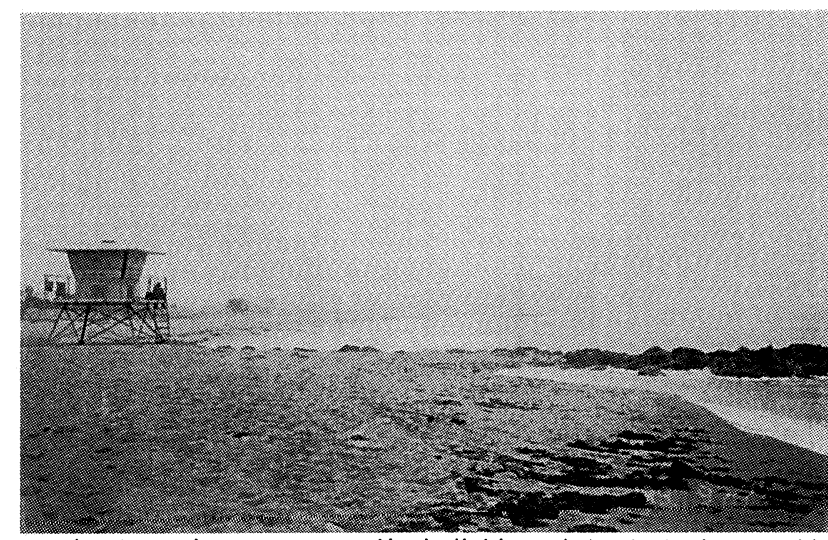

写真-17 ヴェンチュラ海岸北端の突堤左右岸の汀線 状況

以下では,上述の例を参考として, 流砂の系のうち 主として海岸部を中心に今後の検討課題について整 理する.図-2aを参照し, 流砂の系の上流部にダムま たは砂防ダムがあり, その上流で堆砂が生じている とする.これらの施設の直下流では河床低下傾向と なるが,ここでは河川管理上,橋脚や護岸の局所洗掘, 生物を含む河川環境の変化などのマイナス面と, 洪 水流下能力の向上というプラス面を総合的に検討す る必要があるが,ここでは詳細については触れない。

一方, 河川からの土砂供給が沿岸漂砂とバランス していた海岸では,砂碟の供給が完全になくなれば 砂磁浜は消失し,護岸や消波ブロックによって覆わ れた人工海岸となる。海浜は質的変化を遂げ,それ自 体の消失をもたらす.この場合, 図-2aに示すように 土砂を人工的に運搬し,その土砂を海岸へ投入すれ ばよいと簡単に考えられることが多いが,実際には 検討すべき多くの課題がある.

(1)養浜によって砂浜を広げるとして, 広げられた砂 浜の価值をどのように評価するか? 多くの経費をか ければ砂浜面積は大きくできる.しかしその経費が かかることについて広く合意形成ができるか?

(2)養浜が行われようとする場所は,図-2aに示すよう に旧海岸線が後退して現海岸線に至っている.海岸 線の後退は時間的変化を遂げているので,いずれの 時点を復元の目標とすべきか？

(3)侵食を起こした外力は現在もまた作用しているか ら，土砂を投入するだけでは投入土砂は沿岸漂砂に よって運び去られ，投入位置からは急速に失われる

（図-2b参照）.投入土砂の効果はどれだけ継続でき るか? 投入した土砂の流出速度が大き過ぎないか？ 大き過ぎるのであれば, 土砂の流出を抑制する手法 はあるか?

(4)養浜方法の問題として, 図-3に示すように,陸送さ れた土砂を侵食海岸に投入する場合, 侵食の結果汀 線付近の海底勾配は急になっているので, 養浜土砂 は安定な勾配より急勾配で投入されることになる. これは土砂の安定性を損ね, 沖への土砂移動を促進 するはずである。このような現象の予測, およびその 対応策の定量的評価が可能か?

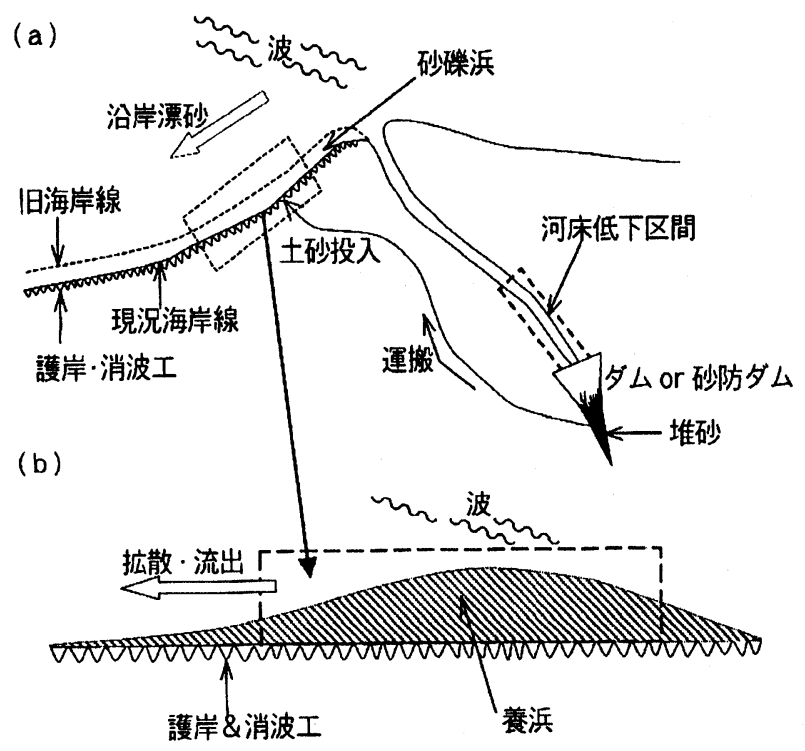

図-2 ダム上流への堆積土砂の運搬と養浜の模式図

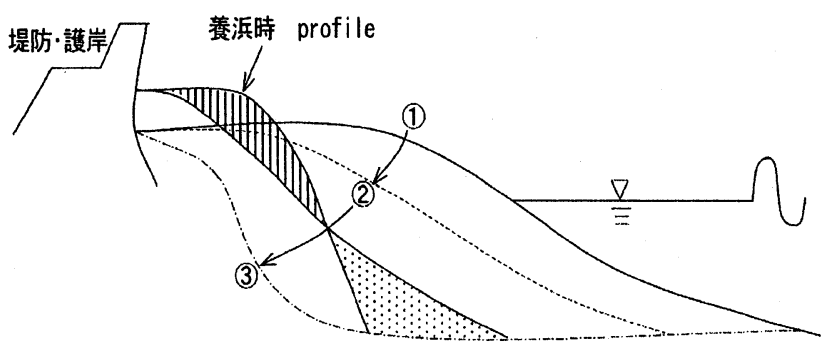

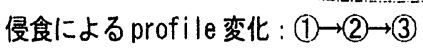

\section{図-3 侵食による海浜勾配の増加と養浜時の縦断形} の変化模式図

(5)図-2aに示したように上流域から土砂を運搬する 場合, 運搬コストのアロケーションをどのように設 定するか?.

これらの課題はいずれも相互に関係しているが, (3), (4)は工学的課題として取り組み易いテーマであ る.(5)は経済的問題であり, (1), (2)は経済的問題に大 きく関与すると同時に海岸の基本的価值観にも関係 する課題である.とくに(2)は(1)と密接に関係してい る.海岸線まで土砂を輸送して養浜するという行為 に要する経費は,最終的には国民負担となるので,経 済合理性と目指すべき（あるいは復元すべき）環境 との整合をいかに取るかの問題に帰着する。一貫し た流砂の系を保持していくためには,海岸技術者も 上述の課題に積極的に取り組む必要があると考える.

\section{参考文献}

1)Gray, J.T.: Sediment management options associated with the removal of Matilija Dam, abstract of Sand Right '99 Bringing Back The Beaches, 1999.

2)Komar, P.D.: Beach processes and sedimentation, PrenticeHall, Inc., Englewood Cliffs, New Jersey, 429p., 1976. 